\title{
Placental development during early pregnancy in sheep: effects of embryo origin on vascularization
}

\author{
Anna T Grazul-Bilska, Mary Lynn Johnson, Pawel P Borowicz, Jerzy J Bilski, Taylor Cymbaluk, \\ Spencer Norberg, Dale A Redmer and Lawrence P Reynolds
}

Department of Animal Sciences, Center for Nutrition and Pregnancy, North Dakota State University, Fargo, North Dakota 58108, USA

Correspondence should be addressed to A T Grazul-Bilska; Email: Anna.Grazul-Bilska@ndsu.edu

\begin{abstract}
Utero-placental growth and vascular development are critical for pregnancy establishment that may be altered by various factors including assisted reproductive technologies (ART), nutrition, or others, leading to compromised pregnancy. We hypothesized that placental vascularization and expression of angiogenic factors are altered early in pregnancies after transfer of embryos created using selected ART methods. Pregnancies were achieved through natural mating (NAT), or transfer of embryos from NAT (NAT-ET), or IVF or in vitro activation (IVA). Placental tissues were collected on day 22 of pregnancy. In maternal caruncles (CAR), vascular cell proliferation was less $(P<0.05)$ for IVA than other groups. Compared with NAT, density of blood vessels was less $(P<0.05)$ for IVF and IVA in fetal membranes (FM) and for NAT-ET, IVF, and IVA in CAR. In FM, mRNA expression was decreased $(P<0.01-0.08)$ in NAT-ET, IVF, and IVA compared with NAT for vascular endothelial growth factor (VEGF) and its receptor FLT1, placental growth factor (PGF), neuropilin 1 (NP1) and NP2, angiopoietin 1 (ANGPT1) and ANGPT2, endothelial nitric oxide synthase 3 (NOS3), hypoxia-inducible factor 1A (HIF1A), fibroblast growth factor 2 (FGF2), and its receptor FGFR2. In CAR, mRNA expression was decreased $(P<0.01-0.05)$ in NAT-ET, IVF, and IVA compared with NAT for VEGF, FLT1, PGF, ANGPT1, and TEK. Decreased mRNA expression for 12 of 14 angiogenic factors across FM and CAR in NAT-ET, IVF, and IVA pregnancies was associated with reduced placental vascular development, which would lead to poor placental function and compromised fetal and placental growth and development.
\end{abstract}

Reproduction (2014) 147 639-648

\section{Introduction}

Placental vascularization is initiated and established early in pregnancy and supports early embryonic survival and subsequent fetal growth and development (Grazul-Bilska et al. 2010, 2011, 2013). Thus, the importance of placental vascular development during early pregnancy has long been recognized (Reynolds et al. 2010, 2013). During early pregnancy, extensive angiogenesis in maternal and fetal placental tissues progresses, accompanied by a marked increase in uterine and umbilical blood flows (Greiss \& Anderson 1970, Reynolds 1986, Reynolds \& Redmer 1995). Placental angiogenesis is tightly regulated by numerous growth and angiogenic factors (Mayhew et al. 2003, 2004a,b, Redmer et al. 2004, Grazul-Bilska et al. 2010, 2011, Reynolds et al. 2010, 2013).

The pattern of placental vascularization and expression of factors that influence angiogenesis during early pregnancy after natural breeding have been established for sheep (Grazul-Bilska et al. 2010, 2011). However, very limited data concerning placental vascularization in pregnancies established after transfer of embryos obtained through assisted reproductive technologies (ART) or pregnancies affected by environmental factors during early stages of development are available. For later stages of pregnancy, it has been demonstrated that factors such as maternal age, inadequate nutrition, environmental pollutants, and others are associated with decreased vascularization and/or blood flow in the placenta of several species (Redmer et al. 2004, Reynolds et al. 2006, 2013, Rennie et al. 2011). Comparison of placental development at several stages of natural pregnancies with those achieved by various ART has shown differences in fetal size, placental and fetal growth, placental steroid metabolism, global DNA methylation, and expression of selected genes in several species (Barnes 2000, Cai et al. 2006, Grazul-Bilska et al. 2006, 2013, Allen et al. 2008, Collier et al. 2009, Delle Piane et al. 2010, Sellers López et al. 2010, Esh-Broder et al. 2011, Tomic \& Tomic 2011, Ptak et al. 2013). In addition, placental vascular development is dramatically altered at term in pregnancies resulting from ART in sheep (Palmieri et al. 2007) and cattle (Hill et al. 2000, Miles et al. 2004, Miglino et al. 2007), and such alterations have been 
shown to occur as early as day 70 of pregnancy in cattle (Miles et al. 2005). Furthermore, reduced placental vascular development and increased vascular resistance during early pregnancy have been associated with early embryonic mortality (Meegdes et al. 1988, Bassil et al. 1995).

Beyond their immediate effects on pregnancy establishment, factors influencing placental vascular development have a dramatic impact on fetal growth and development and therefore on birth weight as well as postnatal survival and growth (Reynolds \& Redmer 2001, Reynolds et al. 2010, 2013). Moreover, it has been shown that such postnatal effects impact not only the postnatal period but also lifelong health and productivity in mammals, including humans and livestock (Nathanielsz 2006, Barker 2007, Vonnahme \& Lemley 2011, Reynolds \& Caton 2012).

We hypothesized that placental vascularization and/or expression of factors involved in the regulation of angiogenesis would be altered very early (2-4 weeks after fertilization) in pregnancies achieved through transfer of embryos from various sources, including those from ART, compared with natural pregnancies. To test this hypothesis, we established pregnancies using a control group that was naturally mated (NAT), as well as three groups involving i) follicle-stimulating hormone (FSH) treatment to induce multiple follicle development (Stenbak et al. 2001, Grazul-Bilska et al. 2007) combined with NAT, embryo flushing, and embryo transfer (ET) to synchronized recipients (NAT-ET); ii) transfer of embryos obtained through IVF of oocytes collected from FSH-treated ewes; and iii) transfer of embryos obtained through in vitro activation (IVA; i.e. parthenotes - clones containing only maternal genes) of oocytes collected from FSH-treated donors, as described before (Grazul-Bilska et al. 2013). Therefore, the aim of this study was to determine vascularization (e.g. vascular labeling index (LI) and the density of blood vessels) and the expression of mRNA for 14 factors involved in the regulation of angiogenesis in fetal and maternal placenta on day 22 of gestation in four pregnancy types: NAT, NAT-ET, IVF, and IVA in sheep.

\section{Materials and methods}

\section{Animals and tissue collection}

The North Dakota State University Institutional Animal Care and Use Committee approved all animal procedures used in this study. Animal use, experimental design, and methodology are described in detail in a recently published paper (Grazul-Bilska et al. 2013). Tissue samples for this and previous (Grazul-Bilska et al. 2013) studies were collected from the same animals, but different measurements were performed. Briefly, estrus was synchronized using a CIDR device for 14 days (MWI, Boise, ID, USA) for adult ewes ( $n=67$; Western Range ewes, primarily Rambouillet, Targhee, and Columbia crossbred) randomly assigned to be NAT or to serve as donors or recipients.
Twenty-four hours after CIDR removal, ewes $(n=10)$ assigned to the NAT group were exposed to a fertile ram. For donor ewes in the NAT-ET, IVF, and IVA groups, estrus was checked twice daily using a vasectomized ram. Donor ewes $(n=3)$ for the NAT-ET group were treated twice daily with FSH-P (Sioux Biochemical, Sioux Center, IA, USA): on day 13 following estrus (day 0), $5 \mathrm{mg}$ /injection; day 14, $4 \mathrm{mg}$ /injection; and day 15 , $3 \mathrm{mg}$ /injection as described before (Stenbak et al. 2001, Grazul-Bilska et al. 2006, 2012). Donor ewes $(n=22)$ for the IVF and IVA groups were treated with FSH-P on days 13 and 14 after estrus, as described above. On day 15 of the estrous cycle, ewes from the NAT-ET group were exposed to a fertile ram for $48 \mathrm{~h}$, but for the ewes in the IVF and IVA groups, ovaries were collected. Then, the oocytes were isolated, matured for $24 \mathrm{~h}$, and fertilized or activated in vitro. To accomplish this, cumulusoocyte complexes (COCs) were isolated from visible surface antral follicles $>3 \mathrm{~mm}$ in diameter and incubated overnight in maturation medium (TCM199; Sigma; up to $30 \mathrm{COC} / 0.5 \mathrm{ml}$ in a four-well Nunc culture dish) supplemented with $10 \%$ fetal bovine serum (FBS, Sigma), ovine FSH ( $5 \mu \mathrm{g} / \mathrm{ml}$; oFSH-RP-1; NIAMDD-NIH, Bethesda, MD, USA), ovine LH $(5 \mu \mathrm{g} / \mathrm{ml}$; oLH-26; NIADDK-NIH), estradiol-17ß (1 $\mu \mathrm{g} / \mathrm{ml} ;$ Sigma), glutamine (2 mM; Sigma), sodium pyruvate $(0.25 \mathrm{mM}$; Sigma), epidermal growth factor (10 ng/ml; Sigma), and penicillin/streptomycin (100 units/ml penicillin and $100 \mu \mathrm{g} / \mathrm{ml}$ streptomycin; Gibco). After denuding oocytes of cumulus cells, half of the oocytes from each ewe were used for IVF and the other half for IVA.

For IVF, capacitated semen pooled from five Western range crossbreed rams frozen and stored in liquid nitrogen $\left(-197^{\circ} \mathrm{C}\right)$ was thawed and viable sperm were separated in the modified sperm washing media (Irvine Scientific, Santa Ana, CA, USA) using the swim-up technique (Grazul-Bilska et al. 2006, 2012). Oocytes were cultured in fertilization medium prepared in our laboratory consisting of synthetic oviductal fluid (SOF), 2\% heat-inactivated ovine serum collected on day $0-1$ of the estrous cycle, and $1 \%$ penicillin/streptomycin in the presence of capacitated sperm $\left(0.5-1 \times 10^{6} \mathrm{sperm} / \mathrm{ml}\right)$ for $24 \mathrm{~h}$ followed by incubation (at $39{ }^{\circ} \mathrm{C}, 5 \% \mathrm{O}_{2}, 5 \% \mathrm{CO}_{2}$, and $90 \% \mathrm{~N}_{2}$ ) in culture medium until ET (Grazul-Bilska et al. 2003, 2006, 2012, 2013). Culture medium consisted of SOF supplemented with BSA ( $8 \mathrm{mg} / \mathrm{ml}$; Sigma), glutamine $(1 \mathrm{mM})$, MEM nonessential amino acids $(0.01 \mathrm{ml} / \mathrm{ml}$, vol/vol; Sigma), BME amino acids (0.02 $\mathrm{ml} / \mathrm{ml}$, vol/vol; Sigma), and penicillin/streptomycin (100 units/ml penicillin and $100 \mu \mathrm{g} / \mathrm{ml}$ streptomycin). For IVA, oocytes were incubated for $5 \mathrm{~min}$ in TCM199 medium containing $2 \%$ FBS and ionomycin $(2.5 \mu \mathrm{M}$; Sigma) followed by a 3-h incubation with 6-dimethylaminopurine $(2 \mathrm{mM}$; Sigma). In vitro-activated oocytes were then transferred to culture medium and incubated until ET (Grazul-Bilska et al. 2003, 2006, 2013).

For the NAT-ET group, on day 5 post-mating (day 1, day of mating), embryos were flushed, evaluated using a stereomicroscope, and then transferred to synchronized recipients (three embryos at morula stage from the same donor/recipient; $n=9$ ). For the IVF and IVA groups, in vitro-generated embryos at morula stage were transferred on day 5 after fertilization or activation (day 1, day of fertilization or activation) to synchronized recipient ewes (three embryos from the same 
donor/recipient; $n=10$ and 13 respectively). On day 22 after mating, fertilization, or activation, fetuses and utero-placental tissues were collected from NAT, NAT-ET, IVF, and IVA groups ( $n=8,7,8$, and 7 ewes respectively). Pregnancy rates for NAT, NAT-ET, IVF, and IVA groups were 80, 78, 80, and 54\% respectively.

Cross sections $(\sim 0.5-\mathrm{cm}$ thick) of the entire gravid uterus including fetal membranes (FM, chorioallantois) were fixed by immersion in formalin for Ki67 detection or Carnoy's solution for smooth muscle cell actin (SMCA) detection and then embedded in paraffin. For total cellular RNA extraction, FM (fetal placenta) and caruncular (CAR, maternal placenta) tissues were dissected from an area close to the embryo, snap-frozen in isopentane super-cooled in liquid nitrogen, and stored at $-70{ }^{\circ} \mathrm{C}$. We chose day 22 for tissue collection because in our previous experiments, we demonstrated that between days 20 and 22, major changes in cell proliferation, vascularization, and expression of angiogenic factors occurred in fetal and maternal placenta in pregnancies achieved through NAT (Grazul-Bilska et al. 2010, 2011). In addition, by days 20-22 after mating, placentation is already initiated in sheep (Igwebuike 2009).

\section{Immunohistochemistry}

Immunohistochemical procedures were performed as described by Grazul-Bilska et al. (2010, 2011, 2013). Briefly, paraffin-embedded uterine tissues containing FM were sectioned at $4 \mu \mathrm{m}$ and mounted onto glass slides. Sections were rinsed several times in PBS containing Triton X-100 (0.3\%, v/v) and then were treated for $20 \mathrm{~min}$ with blocking buffer (PBS containing normal horse serum $(2 \%$, vol/vol) $)$ followed by overnight incubation at $4{ }^{\circ} \mathrm{C}$ with specific primary antibody for Ki67 (a marker of proliferating cells; 1:500; mouse monoclonal; Vector Laboratories, Burlingame, CA, USA) or SMCA (a marker of pericytes and vascular smooth muscle cells and thus blood vessels; 1:150; mouse monoclonal; Oncogene Research Products, San Diego, CA, USA). Primary antibodies were detected using secondary anti-mouse antibody coupled to peroxidase (ImPress Kit; Vector Laboratories). For Ki67 staining, the sections were then counterstained with hematoxylin and periodic acid-Schiff's reagent ( $\mathrm{H}$ and PAS) to visualize cell nuclei as well as basement membranes and thus blood vessels (Reynolds \& Redmer 1992). For SMCA staining, the sections were counterstained with nuclear fast red (Sigma) to visualize cell nuclei. Control sections were incubated with normal mouse IgG $(4 \mu \mathrm{g} / \mathrm{ml})$ in place of primary antibody.

\section{Image analysis}

For each tissue section, images were taken at $600 \times(\mathrm{Ki67}$ staining) or $200 \times$ (SMCA staining) magnification using an Eclipse E600 Nikon microscope and digital camera (Nikon Instruments, Inc., Melville, NY, USA) or Zeiss Imager M2 epifluorescence microscope equipped with Zeiss piezo automated stage and AxioCam HRm camera (Carl Zeiss International, Jena, Germany). Image analysis (Image-Pro Plus, Media Cybernetics, Inc., Bethesda, MD, USA) was performed for images of five to ten randomly chosen fields of CAR to determine vascular cell proliferation based on Ki67 staining, while images of five to 40 randomly chosen fields from areas containing FM or CAR were used to determine the density of blood vessels based on SMCA staining, as described previously (Borowicz et al. 2007, Grazul-Bilska et al. 2010, 2011, 2013). The LI was calculated as the percentage (\%) of proliferating Ki67-positive cells out of the total number of cells within blood vessels that were marked with $\mathrm{H}$ and PAS/CAR tissue area.

\section{Quantitative real-time RT-PCR}

All procedures for determining the expression of mRNA of genes in ovine tissues by RT-PCR along with sequences for 14 factors involved in the regulation of angiogenesis have been reported previously (Redmer et al. 2005, Grazul-Bilska et al. 2010, 2011). Briefly, snap-frozen CAR and FM tissues were homogenized in TRI-reagent (Molecular Research Center, Cincinnati, $\mathrm{OH}, \mathrm{USA}$ ) and RNA was extracted according to the manufacturer's specifications. The quality and quantity of total RNA were determined via capillary electrophoresis using the Agilent 2100 Bioanalyzer (Agilent Technologies, Wilmington, DE, USA). Real-time RT-PCR reagents, probes, and primers were purchased from and used as recommended by Applied Biosystems. For each sample, $30 \mathrm{ng}$ total RNA was reverse transcribed in triplicate $20 \mu \mathrm{l}$ reactions using random hexamers. Sequence-specific TaqMan probes and primers were designed using the Primer Express Software from Applied Biosystems. The ABI PRISM 7000 was used for detection of sequences amplified at $60{ }^{\circ} \mathrm{C}$ typically for 40 or 45 cycles (Applied Biosystems). Quantification was determined from a relative standard curve of dilutions of the cDNA generated from tcRNA pooled from placentomes collected on day 130 of pregnancy. Expression of each gene was normalized to expression of $18 S$ rRNA in a multiplex reaction using the human 18S pre-developed assay reagent (PDAR) from Applied Biosystems. The PDAR solution, which is primer limited and contains a VIC-labeled probe, was further adjusted using onefourth the normal amount, so that it would not interfere with amplification of the FAM-labeled gene of interest. Standard curves were also generated with the multiplex solution, and the quantity of $18 S$ rRNA and the gene of interest were determined using each specific standard curve. The concentrations of mRNA were then normalized to $18 S$ rRNA by dividing each of the mRNA values by their corresponding $18 S \mathrm{rRNA}$ value.

\section{Statistical analysis}

Data were analyzed using the general linear model procedure of SAS (SAS Institute 2010) with the main effect of embryo origin (i.e. NAT, NAT-ET, IVF, or IVA) and presented as means \pm S.E.M. When the $F$-test was significant $(P<0.05)$, differences between specific group means were evaluated using the least significant differences test (Kirk 1982). In addition, PROC CORR of SAS was used to calculate simple linear correlations between specific variables.

\section{Results}

In all pregnancy groups, Ki67 was detected in the nuclei of proliferating cells in blood vessels and other 
compartments of CAR (Fig. 1), and SMCA was detected in the blood vessels in FM and CAR (Fig. 2). LI of vascular cells and the density of blood vessels in CAR and/or FM were affected by embryo origin. For CAR, the vascular $\mathrm{LI}$ was less $(P<0.04)$ in the IVA group compared with any of the other groups, which were similar to each other $(3.2 \pm 1.2$ vs $9.5 \pm 1.3 \%)$. In FM, the density of blood vessels was less $(P<0.01)$ in IVA than in NAT or NAT-ET and was intermediate in IVF (Fig. 3A). In CAR, the density of blood vessels was less $(P<0.01)$ in NAT-ET, IVF, and IVA than in NAT (Fig. 3B). In NAT, the density of blood vessels was $39.1 \pm 3.5$ and $39.4 \pm 4.3 / 10^{6} \mu \mathrm{m}^{2}$ in FM and CAR respectively.

In all pregnancy types, in FM and CAR, mRNA were detected for the following: vascular endothelial growth factor (VEGF) and its receptors, FLT1 and KDR; placental growth factor (PGF); neuropilin 1 (NP1) and NP2; the angiopoietins (ANGPT1 and ANGPT2) and their receptor TEK; endothelial nitric oxide synthase 3 (NOS3) and its receptor soluble guanylate kinase $(G \cup C Y 1 B 3)$; hypoxiainducible factor 1A (HIF1A); and fibroblast growth factor 2 (FGF2) and its receptor FGFR2 (Fig. 4). Compared with NAT, mRNA expression in FM was less $(P<0.01)$ for VEGF and FLT1 in NAT-ET, IVF, and IVA, but KDR mRNA expression was similar for all groups (Fig. 4A).

Compared with NAT, VEGF mRNA expression in CAR was less $(P<0.01)$ in NAT-ET and IVA, whereas IVF was intermediate (Fig. 4B). For FLT1 mRNA in CAR, expression was less $(P<0.01)$ in NAT-ET, IVF, and IVA compared with NAT, but KDR mRNA expression was similar for all groups (Fig. 4B).

Compared with NAT, mRNA expression in FM was less for $P G F(P<0.05)$ in NAT-ET and IVF but was intermediate for IVA (Fig. 4C). Expression of mRNA in FM was less for NP1 $(P<0.08)$ in NAT-ET, IVF, and IVA compared with NAT (Fig. 4C). In addition, in FM, mRNA expression for
NP2 was greater in NAT-ET $(P<0.02)$ than in IVF and IVA, and NAT was intermediate (Fig. 4C). Compared with NAT, $P G F$ mRNA expression in CAR was less $(P<0.01)$ in NAT-ET, IVF, and IVA, but mRNA expression for NP1 and NP2 was similar for all groups (Fig. 4D).

Compared with NAT, mRNA expression in FM was less $(P<0.01)$ for ANGPT1 in NAT-ET, IVF, and IVA (Fig. 4E). Expression of ANGPT2 mRNA in FM was less $(P<0.05)$ in NAT-ET and IVA but not in IVF (Fig. 4E). Expression of TEK mRNA was similar in FM of all groups (Fig. 4E).

Compared with NAT, mRNA expression in CAR was less $(P<0.01)$ for ANGPT1 in NAT-ET, IVF, and IVA, but ANGPT2 mRNA expression was similar for all groups (Fig. 4F). Compared with NAT, TEK mRNA expression in CAR was less $(P<0.01)$ for IVF and IVA but was intermediate in NAT-ET (Fig. 4F).

Compared with NAT, mRNA expression in FM was less $(P<0.03)$ for NOS3 and HIF1A in NAT-ET and IVA, but in the IVF group, it was either intermediate (NOS3) or similar (HIF1A) to that of the NAT group (Fig. 4G). In FM, mRNA expression for GUCY1B3 was similar for all groups (Fig. 4G). In CAR, mRNA expression of NOS3, GUCY1B3, and HIF1A (Fig. 4H) and for FGF2 and FGFR2 (Fig. 4J) was similar for all groups.

Compared with NAT, mRNA expression in FM was less $(P<0.06)$ for FGF2 in NAT-ET, IVF, and IVA and for FGFR2 in FM was less $(P<0.07)$ in NAT-ET and IVF but intermediate for IVA (Fig. 4I).

Supplementary Tables 1 and 2 (see section on supplementary data given at the end of this article) present correlation coefficients for mRNA expression among factors involved in the regulation of angiogenesis and the density of blood vessels in FM and CAR respectively. For FM, the VEGF system members were correlated with the ANGPT and FGF systems and with eNOS; there were 39 statistically significant correlations
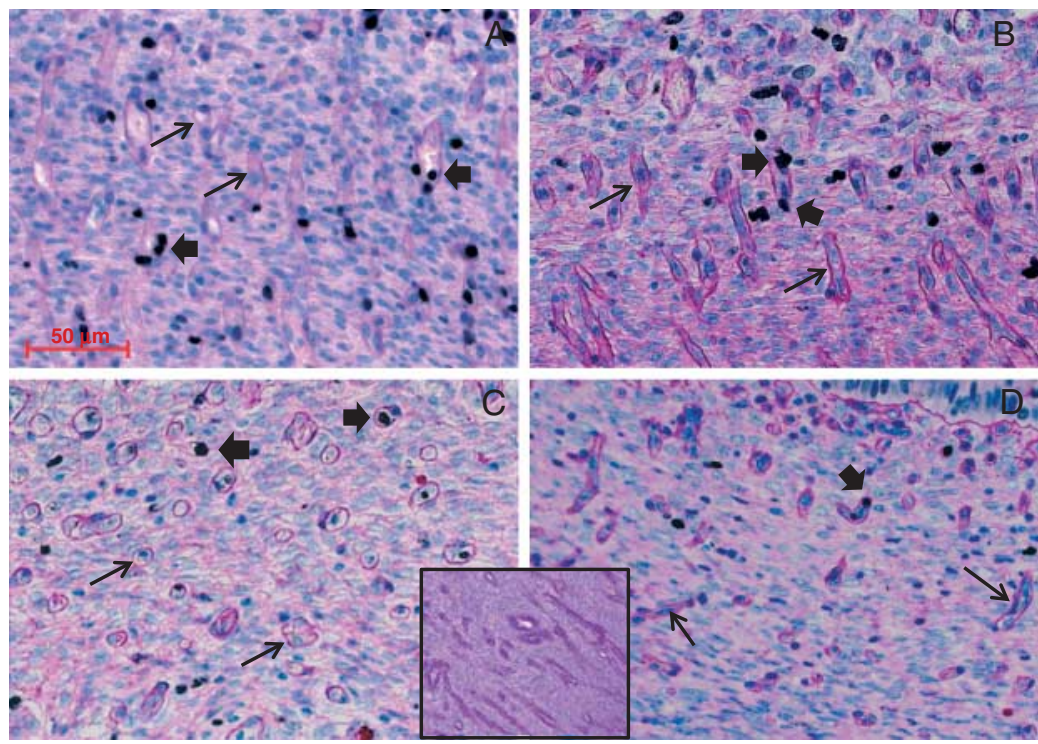

Figure 1 Representative photomicrographs of immunohistochemical detection of Ki67 (blackish nuclei, large arrows) followed by hematoxylin (bluish nuclei) and PAS (dark pink staining of basement membranes) staining in CAR from NAT (A), NAT-ET (B), IVF (C), and IVA (D) groups on day 22 of pregnancy. Small arrows indicate examples of blood vessels and large arrows point to examples of proliferating cells (Ki67-positive nuclei) within blood vessels. Bar on A (valid for B-D) $=50 \mu \mathrm{m}$. In inset in C/D, note the lack of positive Ki67 staining in the control sections in which non-specific mouse $\lg \mathrm{G}$ was used in place of the primary antibody. 


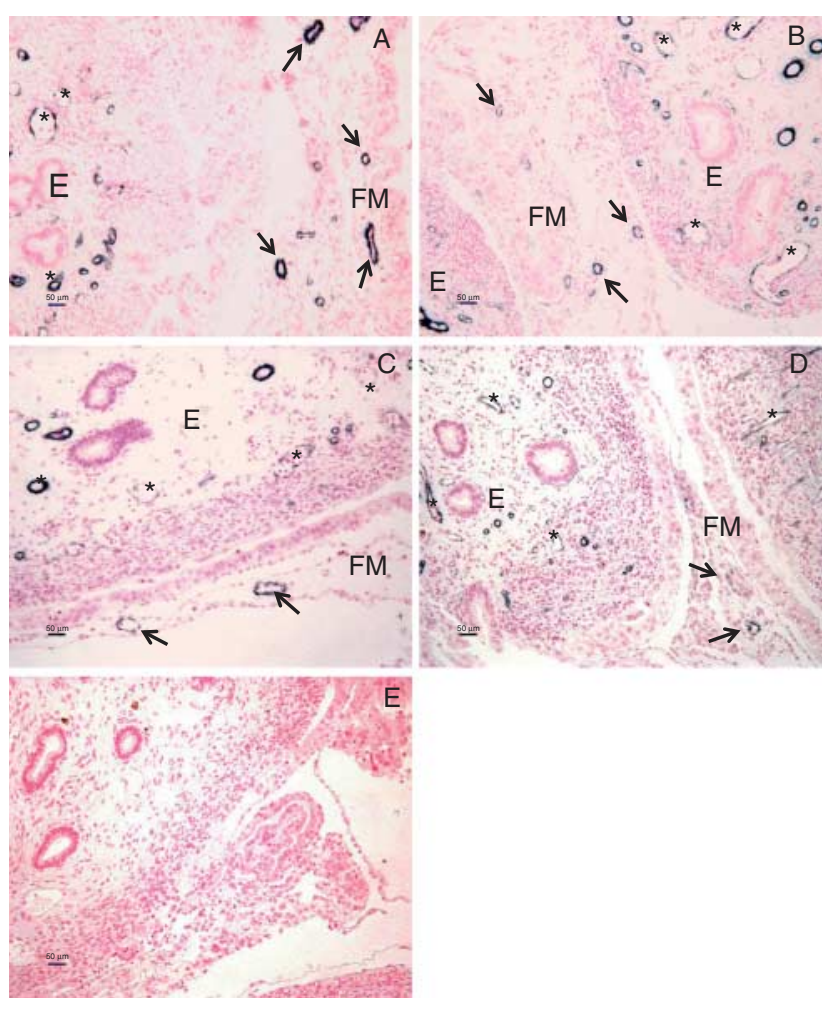

Figure 2 Representative photomicrographs of immunohistochemical detection of SMCA (blackish staining) followed by fast red (pinkish cell nuclei) staining in FM and endometrial (E) CAR from NAT (A), NAT-ET (B), IVF (C), and IVA (D) groups on day 22 of pregnancy. Arrows indicate blood vessels in FM and stars in E of CAR in A, B, C and D. Bar $=50 \mu \mathrm{m}$ for A, B, C, D and E. In E, note the lack of positive SMCA staining in the control sections in which non-specific mouse IgG was used in place of the primary antibody.

among these factors. In addition, for FM, ANGPT2 and eNOS were correlated with blood vessel density. For CAR, the VEGF system members were correlated with the ANGPT and FGF systems, and several factors $(n=8)$ were correlated with the density of blood vessels. For CAR, there were 48 statistically significant correlations among these factors.

\section{Discussion}

This study demonstrated that embryo origin and application of selected ART methods affect placental vascular development and mRNA expression of factors involved in the regulation of angiogenesis in fetal and placental tissues at a specific time point (day 22) in early pregnancy. In fact, several measurements of vascularization/angiogenesis were decreased after transfer of embryos of different origin. Interestingly, altered blood flow, vascular development, and/or expression of selected angiogenic and/or other growth factors have been demonstrated in the placenta of mid to late pregnancies compromised by factors causing fetal growth restrictions in several species
(Reynolds et al. 2006, 2013, Vonnahme \& Lemley 2011, Gourvas et al. 2012).

In this study, decreased vascular cell proliferation in maternal placenta was observed only in the IVA group. This demonstrates that when embryos possess only maternal genes, cell proliferation in blood vessels of CAR appears to be altered. Thus, input of the paternal genome seems to be critical for blood vessel growth and development in the maternal placenta. Previously, we have demonstrated that the total cell proliferation in fetal and maternal placental tissues for the same pregnancy types was decreased in NAT-ET, IVF, and IVA groups compared with NAT (Grazul-Bilska et al. 2013). Thus, it seems that embryo origin has limited effects on placental blood vessel growth but has more extensive effects on overall placental tissue growth in the early stages of pregnancy. Therefore, we hypothesize that the mechanisms of regulation of blood vessel cell proliferation differ from those involved in the regulation of proliferation of other cell types in the placenta.

A reduced density of blood vessels in FM or CAR was observed in NAT-ET, IVF, or IVA groups in this study. This may be associated with reduced overall growth measured by cell proliferation in FM and CAR reported before for the same animal models (Grazul-Bilska et al. 2013). In addition, the IVA group had the lowest density
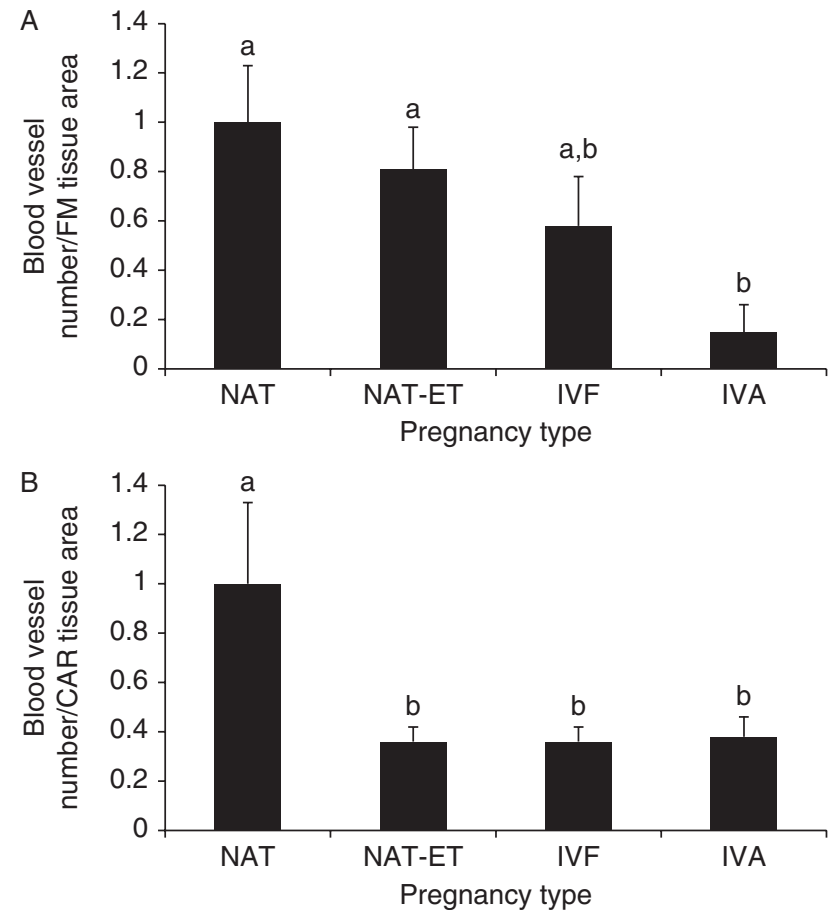

Figure 3 The density of blood vessels (based on SMCA staining) in FM (A) and CAR (B) from NAT, NAT-ET, IVF, and IVA groups on day 22 of pregnancy. Data are expressed as a fold-change compared with the NAT group, which was arbitrarily set as 1 . In NAT, the density of blood vessels was $39.1 \pm 3.5$ and $39.4 \pm 4.3 / 10^{6} \mu \mathrm{m}^{2}$ in FM and CAR respectively. Means \pm S.E.M. with different superscript letters differ within tissue $\left({ }^{a, b} P<0.01\right)$. 

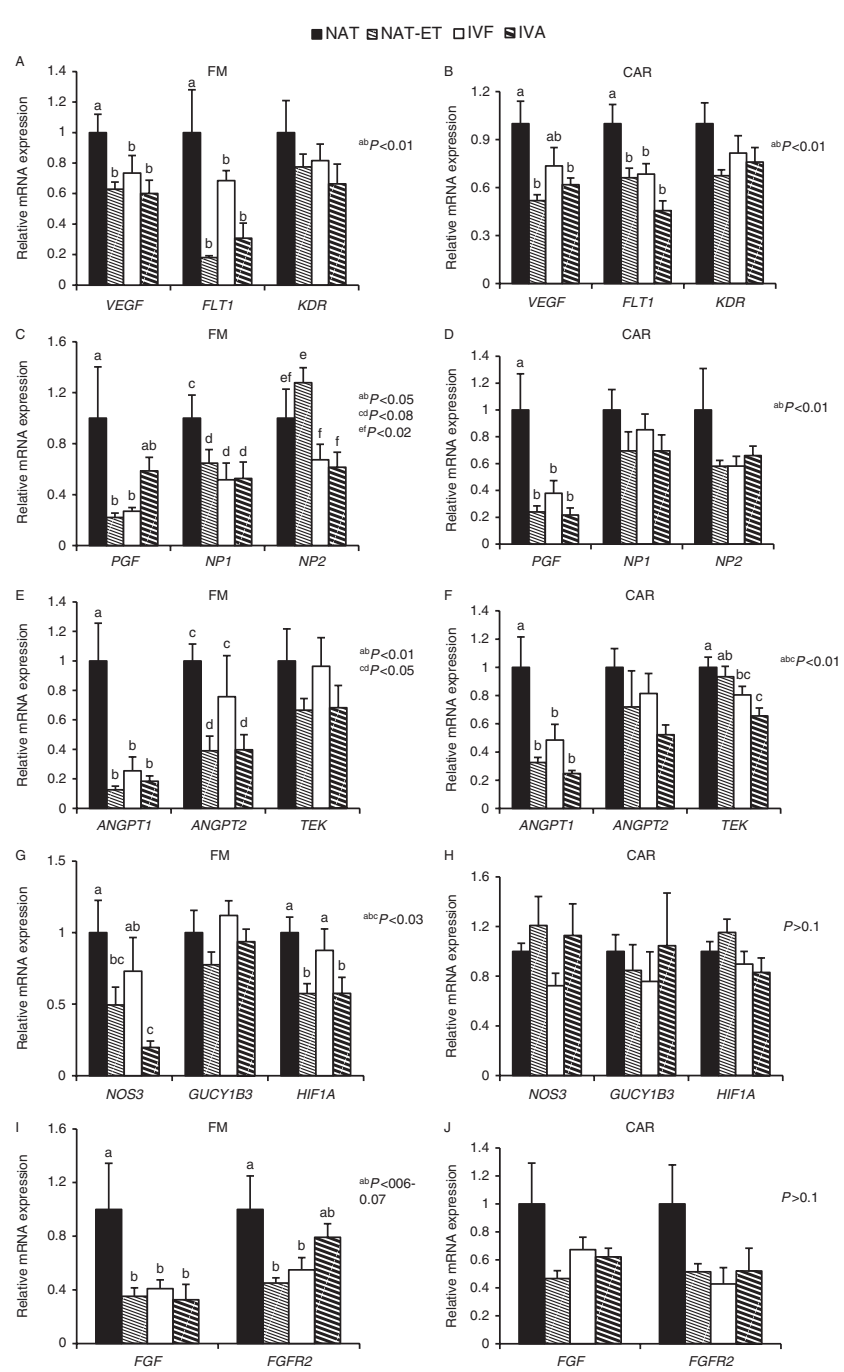

Figure 4 Expression of mRNA for $V E G F, F L T 1, K D R$ (A and B), $P G F$, $N P 1, N P 2$ (C and D), ANGPT1, ANGPT2, TEK (E and F), NOS3, GUCY1B3, HIF1A (G and $\mathrm{H}), F G F 2$, and FGFR2 (I and $\mathrm{J}$ ) in FM (left column: A, C, E, G and I) or CAR (right column: B, D, F, H and J) from NAT, NAT-ET, IVF, and IVA groups on day 22 of pregnancy. Data are expressed as fold-change compared with NAT control arbitrarily set as 1 . Means \pm S.E.M. with different superscript letters differ within a specific gene $\left({ }^{\mathrm{a}, \mathrm{b}, \mathrm{c}, \mathrm{d}, \mathrm{e}, \mathrm{f} f} P<0.01-0.08\right)$.

of blood vessels in FM, and a very low vascular cell proliferation in CAR. These data indicate that in the absence of the paternal genome, fetal-maternal interactions are altered causing profoundly reduced vascularization in the maternal placenta.

Reduced vascular density in maternal and fetal placenta in pregnancies achieved after transfer of embryos created through IVF or oocyte activation reported in this study indicates that angiogenesis was impaired during early pregnancy. Therefore, application of ART may lead to inadequate placental vascularization and thus blood flow at least during early gestation and may eventually contribute to compromised pregnancy.
Numerous factors are involved in the regulation of vascular function and growth in the placenta, including members of the VEGF, ANGPT, FGF, HIF families, and the NO system (Reynolds \& Redmer 1995, 2001, Patan 2000, Zygmunt et al. 2003, Demir et al. 2007, Burton et al. 2009, Reynolds et al. 2010). Expression and function of these factors depend on stage of pregnancy, maternal age, and environmental and other factors (Reynolds et al. 2010, 2013). In this study, the mRNA expression of 12 of 14 evaluated factors involved in the regulation of angiogenesis was decreased in FM and/or CAR in NATET, IVF, and/or IVA groups compared with the NAT control. Expression of mRNA for only two factors in placental tissues, KDR and GUCY1B3, remained unaffected by embryo origin in this study.

Factors belonging to the VEGF family, including VEGF, FLT1, and PGF along with NP1 and NP2, which are involved in the VEGF and PGF signaling, and also members belonging to the ANGPT family are recognized as the major angiogenic factors in placental and other tissues (Ahmed \& Perkins 2000, Reynolds \& Redmer 2001, Neufeld et al. 2002, Wulff et al. 2003, Reynolds et al. 2005, 2010, Chaballe et al. 2011, Koch et al. 2011). Expression of these factors has been demonstrated in maternal and/or fetal placenta from early to late pregnancy in sheep and other species (Reynolds \& Redmer 2001, Borowicz et al. 2007, Grazul-Bilska et al. 2010, 2011, Reynolds et al. 2010, 2013). In our study, mRNA expression for several members of the VEGF family and NP1 or NP2 was reduced in pregnancies achieved using ART. Furthermore, in compromised pregnancies such as those involving intrauterine growth restriction (IUGR), preeclampsia, or delivery of smallfor-gestational age neonates, altered placental expression of members of the VEGF or ANGPT families, vascularization, plasma concentration of PGF and VEGF, or a balance between various angiogenic and/or antiangiogenic factors from mid to late stages have all been reported for humans and other species (Ahmed \& Perkins 2000, Regnault et al. 2002, Wulff et al. 2003, Redmer et al. 2005, 2009, Arroyo \& Winn 2008, Erez et al. 2008). Thus, expression of members of the VEGF and ANGPT families are altered in specific pregnancy disorders at mid to late stages and early pregnancies achieved by transfer of embryos created through ART or oocyte activation. This indicates that changes in expression and possibly function of these factors may contribute to pregnancy disorders.

In FM, but not in CAR, expression of NOS3 and FGF2 mRNA, but not GUCY1B3 or FGFR2, was affected by embryo origin in this study. Furthermore, expression of HIF1A mRNA in CAR but not in FM was affected by embryo origin. Members of the NO and FGF systems and HIF1A are expressed throughout pregnancy in the placenta of several species (Reynolds \& Redmer 2001, Kwon et al. 2004, Grazul-Bilska et al. 2010, 2011, Patel et al. 2010, Reynolds et al. 2010, Krause et al. 2011). 
It has been demonstrated that placental eNOS and/or HIF1A expression was reduced or altered in human preeclampsia at term (Rajakumar et al. 2007) and also in an ovine model of IUGR at mid to late stages (Galan et al. 2001, Ziebell et al. 2007). This indicates that expression and likely function of these factors are affected in compromised pregnancies and therefore may contribute to abnormal placental and/or fetal development.

The NO system members interact with members of VEGF, ANGPT, and FGF families, and they also play a regulatory role in placental angiogenesis, remodeling, and immunosuppression (Purcell et al. 1999, Ahmed \& Perkins 2000, Reynolds \& Redmer 2001, Mata-Greenwood et al. 2008, Grazul-Bilska et al. 2010, 2011, Reynolds et al. 2010, Krause et al. 2011). The HIF1A and other members of the HIF family are involved in regulation of placental growth, remodeling, differentiation, transport, and vascularization acting as key mediators of placental development and function and are therefore likely to be important contributors to both normal and adverse pregnancy outcomes (Pringle et al. 2010). Reduced expression of selected genes mentioned above may contribute to inadequate vascularization and blood flow to the fetus.

Reduced expression of several key factors regulating tissue growth and also vascular function in the placenta, including PGF, HIF1A, FGF2, and their receptors (Shimizu et al. 2012), probably resulted in decreased placental cell proliferation and fetal size observed in our previous study using the same animal models (GrazulBilska et al. 2013). In addition, it has been recently demonstrated that expression of several imprinted genes (e.g. IGF2, H19, and PEG1) was less in FM in pregnancies achieved after ET of embryos created in vitro compared with natural early pregnancies (Ptak et al. 2013). This indicates that impaired tissue growth is associated with changes in expression of selected growth factors, as we observed in this study, and likely with imprinted genes.

Numerous factors involved in the regulation of angiogenesis interact with each other in order to control blood vessel function and development (Reynolds \& Redmer 2001, Borowicz et al. 2007, Grazul-Bilska et al. 2010, Reynolds et al. 2010, 2013), which is reflected by significant correlations among these factors reported for FM and CAR in this study (Supplementary Tables 1 and 2). Furthermore, correlations between eight (of 14) evaluated factors with the density of blood vessels in CAR observed in our study indicate functional associations between mRNA expression and blood vessel growth. The density of blood vessels in FM was correlated with expression of two factors, which indicates a different pattern of blood vessel growth and its regulation in fetal vs maternal placenta.

In this study, tissues were collected only at one stage of early pregnancy (day 22) after transfer of embryos of different origin and application of selected ART including estrus synchronization using CIDR devices,
FSH treatment, IVF or IVA, and ET. These procedures were associated with a decrease in expression of several genes involved in the regulation of angiogenesis in FM and/or CAR. Thus, selected ART methods, including estrus synchronization, superovulatory treatments, and ET with or without IVF or IVA, which are used in animal production and human reproductive medicine, may have some negative effects on fetal and placental growth and function during pregnancy (Sinclair 2008, Laprise 2009). In addition, it has recently been demonstrated that a specific estrus synchronization protocol may affect CAR vascular development during early pregnancy in sheep (Ruiz-Gonzalez et al. 2013), and FSH-superovulatory treatment affected gene expression in bovine granulosa cells, which may lead to altered function (Dias et al. 2013). Conversely, in several experiments in which we used a similar estrus synchronization and/or FSH treatment protocol as in this study, the rates of fertilization or blastocyst formation, and the development of fetuses or offspring in sheep, seemed to be normal (Grazul-Bilska et al. 2003, 2006, 2013). Although others and we observed changes in placental tissue growth, vascularization, expression of selected genes, and global methylation after application of ART during early pregnancy (GrazulBilska et al. 2013, Ptak et al. 2013, Ruiz-Gonzalez et al. 2013), some compensatory mechanisms probably exist to minimize adverse effects of ART during early pregnancy and allow for normal fetal and placental growth and function throughout pregnancy and postnatal period. Alternatively, as pregnancies resulting from various ART, including IVF and somatic cell nuclear transfer (SCNT), may exhibit poor placental development and vascularization as well as abnormal/altered fetal growth and development at different stages of gestation (Hoffert et al. 2005, Farin et al. 2006, Bauersachs et al. 2009, Collier et al. 2009, Mansouri-Attia et al. 2009, Ptak et al. 2013), the effects observed during early pregnancy in this study could have long-term consequences for pregnancy outcome. To determine long-term consequences of ART application, additional studies should be undertaken using offspring created through use of selected ART.

As we have discussed in our previous studies using different embryo origin and also ART (Grazul-Bilska et al. 2013), the embryo affects uterine function and has an active role in initiation of pregnancy and, in turn, the uterus affects fetal growth and development (Reynolds \& Redmer 1995, 2001, Barnea 2004, Spencer et al. 2008, Ostrup et al. 2011, Grazul-Bilska et al. 2013). In fact, abnormal embryo/fetal-maternal communication, endometrial remodeling, reduced vascularization, altered expression of angiogenic factors, and other problems during the peri-implantation and later pregnancy periods have been observed for pregnancies achieved after transfer of embryos created through SCNT in animal models (Hill et al. 2000, Miles et al. 2004, 2005, Loi et al. 2005, Fletcher et al. 2007, Miglino et al. 2007, 
Palmieri et al. 2007, 2008, Campos et al. 2010). However, in pregnancies resulting from the transfer of embryos created through IVF, changes in endometrial vascularization, remodeling, and function were less pronounced than after transfer of embryos from SCNT (Hill et al. 2000, Miles et al. 2004, 2005, Hoffert et al. 2005, Miglino et al. 2007, Palmieri et al. 2007, 2008, Mansouri-Attia et al. 2009). As we discussed before (Grazul-Bilska et al. 2013), endometrial tissues possess mechanisms to adapt to embryos of different origin, which may serve as a biological sensor to meet embryonic demands or adaptation to environmental conditions (Fleming et al. 2004, Borowicz \& Reynolds 2010, Coan et al. 2010). This idea is in line with our hypothesis that during pregnancy, some compensatory mechanisms may exist to reverse negative effects of embryo manipulations on placental and fetal growth.

In summary, in this study, transfer of embryos of different origins and application of ART decreased vascular cell proliferation in CAR, the density of blood vessels in FM and CAR, and expression of several factors involved in the regulation of placental angiogenesis on day 22 of pregnancy. Thus, embryo origin may have specific effects on vascular growth and likely function in the ovine placenta and fetus through regulation of tissue growth and angiogenesis, as well as other mechanisms such as epigenetic processes. As relatively few studies have focused on evaluation of selected processes in the placenta during early gestation without or with application of ART in any species, these data provide novel information concerning fetal and placental vascular growth/cell proliferation and angiogenesis in relation to embryo origin. Furthermore, these data provide a foundation for determining the expression of specific factors regulating vascular development and function of placental and embryonic tissues in pregnancies after application of ART. In addition, these data will help us to better understand placental regulatory mechanisms in compromised pregnancies and to identify strategies for rescuing such pregnancies.

\section{Supplementary data}

This is linked to the online version of the paper at http://dx.doi. org/10.1530/REP-13-0663.

\section{Declaration of interest}

The authors declare that there is no conflict of interest that could be perceived as prejudicing the impartiality of the research reported.

\section{Funding}

This project was supported by USDA grant (2007-01215) to L P Reynolds and A T Grazul-Bilska, NIH grant (HL64141) to L P Reynolds and D A Redmer, Hatch Projects ND01712 to A T Grazul-Bilska and ND1727 to L P Reynolds and D A Redmer, and NSF MRI-R2-ARRA (0959512) grant to A T Grazul-Bilska.

\section{Acknowledgements}

The authors acknowledge Dr Kimberly Vonnahme, Ms Tammi Neville, Mr James D Kirsch, Mr Kim C Kraft, Mr Robert Weigl, Mr Terry Skunberg and other members of our laboratories and department for their assistance, and Dr Jodie Haring for critical review of this manuscript.

\section{References}

Ahmed A \& Perkins J 2000 Angiogenesis and intrauterine growth restriction. Baillière's Best Practice \& Research. Clinical Obstetrics \& Gynaecology 14 981-998. (doi:10.1053/beog.2000.0139)

Allen C, Bowdin S, Harrison RF, Sutcliffe AG, Brueton L, Kirby G, KirkmanBrown J, Barrett C, Reardon W \& Maher E 2008 Pregnancy and perinatal outcomes after assisted reproduction: a comparative study. Irish Journal of Medical Science 177 233-241. (doi:10.1007/s11845-008-0172-9)

Arroyo JA \& Winn VD 2008 Vasculogenesis and angiogenesis in the IUGR placenta. Seminars in Perinatology 32 172-177. (doi:10.1053/j.semperi. 2008.02.006)

Barker DJ 2007 The origins of the developmental origins theory. Journal of Internal Medicine 261 412-417. (doi:10.1111/j.1365-2796.2007.01809.x)

Barnea ER 2004 Insight into early pregnancy events: the emerging role of the embryo. American Journal of Reproductive Immunology $\mathbf{5 1}$ 319-322. (doi:10.1111/j.1600-0897.2004.00159.x)

Barnes FL 2000 The effects of the early uterine environment on the subsequent development of embryo and fetus. Theriogenology $\mathbf{5 3}$ 649-658. (doi:10.1016/S0093-691X(99)00264-2)

Bassil S, Magritte JP, Roth J, Nisolle M, Donnez J \& Gordts S 1995 Uterine vascularity during stimulation and its correlation with implantation in in-vitro fertilization. Human Reproduction 10 1497-1501. (doi:10.1093/ HUMREP/10.6.1497)

Bauersachs S, Ulbrich SE, Zakhartchenko V, Minten M, Reichenbach M, Reichenbach HD, Blum H, Spencer TE \& Wolf E 2009 The endometrium responds differently to cloned versus fertilized embryos. PNAS 106 5681-5686. (doi:10.1073/pnas.0811841106)

Borowicz PP \& Reynolds LP 2010 Placental programming: more may still be less. Perspective. Journal of Physiology 588 393. (doi:10.1113/jphysiol. 2009.185983)

Borowicz PP, Arnold DR, Johnson ML, Grazul-Bilska AT, Redmer DA \& Reynolds LP 2007 Placental growth throughout the last two-thirds of pregnancy in sheep: vascular development and angiogenic factor expression. Biology of Reproduction 76 259-267. (doi:10.1095/biolreprod.106.054684)

Burton GJ, Charnock-Jones DS \& Jauniaux E 2009 Regulation of vascular growth and function in the human placenta. Reproduction 138 895-902. (doi:10.1530/REP-09-0092)

Cai LY, Izumi S, Koido S, Uchida N, Suzuki T, Matsubayashi H, Sugi T, Shida N, Kikuchi K \& Yoshikata K 2006 Abnormal placental cord insertion may induce intrauterine growth restriction in IVF-twin pregnancies. Human Reproduction 21 1285-1290. (doi:10.1093/humrep/dei494)

Campos DB, Papa PC, Marques JE Jr, Garbelotti F, Fatima LA, Artoni LP, Birgel EH, Meirelles FV, Buratini J, Leiser R et al. 2010 Somatic cell nuclear transfer is associated with altered expression of angiogenic factor system in bovine placentomes at term. Genetics and Molecular Research 9 309-323. (doi:10.4238/vol9-1gmr729)

Chaballe L, Schoenen J \& Franzen R 2011 Placental growth factor: a tissue modelling factor with therapeutic potentials in neurology? Acta Neurologica Belgica 111 10-17.

Coan PM, Vaughan OR, Sekita Y, Finn SL, Burton GJ, Constancia M \& Fowden AL 2010 Adaptations in placental phenotype support fetal growth during undernutrition of pregnant mice. Journal of Physiology 588 527-538. (doi:10.1113/jphysiol.2009.181214) 
Collier AC, Miyagi SJ, Yamauchi Y \& Ward MA 2009 Assisted reproduction technologies impair placental steroid metabolism. Journal of Steroid Biochemistry and Molecular Biology 116 21-28. (doi:10.1016/j.jsbmb. 2009.04.005)

Delle Piane L, Lin W, Liu X, Donjacour A, Minasi P, Revelli A, Maltepe E \& Rinaudo PF 2010 Effect of the method of conception and embryo transfer procedure on mid-gestation placenta and fetal development in an IVF mouse model. Human Reproduction 25 2039-2046. (doi:10.1093/ humrep/deq165)

Demir R, Seval Y \& Huppertz B 2007 Vasculogenesis and angiogenesis in the early human placenta. Acta Histochemica 109 257-265. (doi:10.1016/j.acthis.2007.02.008)

Dias FC, Khan MI, Sirard MA, Adams GP \& Singh J 2013 Differential gene expression of granulosa cells after ovarian superstimulation in beef cattle. Reproduction 146 181-191. (doi:10.1530/REP-13-0114)

Esh-Broder E, Ariel I, Abas-Bashir N, Bdolah Y \& Celnikier DH 2011 Placenta accreta is associated with IVF pregnancies: a retrospective chart review. BJOG: an International Journal of Obstetrics and Gynaecology 118 1084-1089. (doi:10.1111/j.1471-0528.2011.02976.x)

Erez O, Romero R, Espinoza J, Fu W, Todem D, Kusanovic JP, Gotsch F, Edwin S, Nien JK, Chaiworapongsa T et al. 2008 The change in concentrations of angiogenic and anti-angiogenic factors in maternal plasma between the first and second trimesters in risk assessment for the subsequent development of preeclampsia and small-for-gestational age. Journal of Maternal-Fetal \& Neonatal Medicine 21 279-287. (doi:10.1080/14767050802034545)

Farin PW, Piedrahita JA \& Farin CE 2006 Errors in development of fetuses and placentas from in vitro-produced bovine embryos. Theriogenology 65 178-191. (doi:10.1016/j.theriogenology.2005.09.022)

Fleming TP, Kwong WY, Porter R, Ursell E, Fesenko I, Wilkins A, Miller DJ, Watkins AJ \& Eckert JJ 2004 The embryo and its future. Biology of Reproduction 71 1046-1054. (doi:10.1095/biolreprod.104.030957)

Fletcher CJ, Roberts CT, Hartwich KM, Walker SK \& McMillen IC 2007 Somatic cell nuclear transfer in the sheep induces placental defects that likely precede fetal demise. Reproduction 133 243-255. (doi:10.1530/rep.1.01203)

Galan HL, Regnault TR, Le Cras TD, Tyson RW, Anthony RV, Wilkening RB \& Abman SH 2001 Cotyledon and binucleate cell nitric oxide synthase expression in an ovine model of fetal growth restriction. Journal of Applied Physiology 90 2420-2426.

Gourvas V, Dalpa E, Konstantinidou A, Vrachnis N, Spandidos DA \& Sifakis S 2012 Angiogenic factors in placentas from pregnancies complicated by fetal growth restriction. Molecular Medicine Reports 6 23-27.

Grazul-Bilska AT, Choi JT, Bilski JJ, Weigl RM, Kirsch JD, Kraft KC, Reynolds LP \& Redmer DA 2003 Effects of epidermal growth factor on early embryonic development after in vitro fertilization of oocytes collected from ewes treated with follicle stimulating hormone. Theriogenology 59 1453-1461. (doi:10.1016/S0093-691X(02)01192-5)

Grazul-Bilska AT, Pant D, Luther JS, Choi JT, Borowicz P, Navanukraw C, Kirsch JD, Kraft KC, Weigl RM, Redmer DA et al. 2006 Pregnancy rates and gravid uterine parameters in single, twin and triplet pregnancies in naturally bred ewes and ewes after transfer of in vitro produced embryos. Animal Reproduction Science 92 268-283. (doi:10.1016/j.anireprosci. 2005.06.013)

Grazul-Bilska AT, Kirsch JD, Bilski JJ, Kraft KC, Windorski EJ, Luther JS, Vonnahme KA, Reynolds LP \& Redmer DA 2007 Superovulation in sheep: number and weight of the corpora lutea and serum progesterone. Sheep and Goat Research Journal 22 26-31.

Grazul-Bilska AT, Borowicz PP, Johnson ML, Minten MA, Bilski JJ, Wroblewski R, Redmer DA \& Reynolds LP 2010 Placental development during early pregnancy in sheep: vascular growth and expression of angiogenic factors in maternal placenta. Reproduction 140 165-174. (doi:10.1530/REP-09-0548)

Grazul-Bilska AT, Johnson ML, Borowicz PP, Minten M, Wroblewski R, Coupe LR, Redmer DA \& Reynolds LP 2011 Placental development during early pregnancy in sheep: cell proliferation, global methylation and angiogenesis in fetal placenta. Reproduction 141 529-540. (doi:10.1530/REP-10-0505)

Grazul-Bilska AT, Borowczyk E, Bilski JJ, Reynolds LP, Redmer DA, Caton JS \& Vonnahme KA 2012 Overfeeding and underfeeding have detrimental effects on oocyte quality measured by in vitro fertilization and early embryonic development in sheep. Domestic Animal Endocrinology 43 289-298. (doi:10.1016/j.domaniend.2012.05.001)
Grazul-Bilska AT, Johnson ML, Borowicz PP, Baranko L, Redmer DA \& Reynolds LP 2013 Placental development during early pregnancy in sheep: effects of embryo origin on fetal and placental growth, and global methylation. Theriogenology 79 94-102. (doi:10.1016/j.theriogenology. 2012.09.013)

Greiss FC \& Anderson SG 1970 Uterine blood flow during early ovine pregnancy. American Journal of Obstetrics and Gynecology 10630.

Hill JR, Burghardt RC, Jones K, Long CR, Looney CR, Shin T, Spencer TE, Thompson JA, Winger QA \& Westhusin ME 2000 Evidence for placental abnormality as the major cause of mortality in first-trimester somatic cell cloned bovine fetuses. Biology of Reproduction 63 1787-1794. (doi:10.1095/biolreprod63.6.1787)

Hoffert KA, Batchelder CA, Bertolini M, Moyer AL, Famula TR, Anderson DL \& Anderson GB 2005 Measures of maternal-fetal interaction in day-30 bovine pregnancies derived from nuclear transfer. Cloning and Stem Cells 7 289-305. (doi:10.1089/clo.2005.7.289)

Igwebuike UM 2009 A review of uterine structural modifications that influence conceptus implantation and development in sheep and goats. Animal Reproduction Science 112 1-7. (doi:10.1016/j.anireprosci.2008.12.010)

Kirk RE 1982 In Experimental Design: Procedures for the Behavioral Sciences, 2nd edn. Belmont, CA: Brooks/Cole.

Koch S, Tugues S, Li X, Gualandi L \& Claesson-Welsh L 2011 Signal transduction by vascular endothelial growth factor receptors. Biochemical Journal 437 169-183. (doi:10.1042/BJ20110301)

Krause BJ, Hanson MA \& Casanello P 2011 Role of nitric oxide in placental vascular development and function. Placenta 32 797-805. (doi:10.1016/ j.placenta.2011.06.025)

Kwon H, Wu G, Meininger CJ, Bazer FW \& Spencer TE 2004 Developmental changes in nitric oxide synthesis in the ovine placenta. Biology of Reproduction 70 679-686. (doi:10.1095/biolreprod.103.023184)

Laprise SL 2009 Implications of epigenetics and genomic imprinting in assisted reproductive technologies. Molecular Reproduction and Development 76 1006-1018. (doi:10.1002/mrd.21058)

Loi P, Clinton M, Vackova I, Fulka J Jr, Feil R, Palmieri C, Della Salda L \& Ptak G 2005 Placental abnormalities associated with post-natal mortality in sheep somatic cell clones. Theriogenology 65 1110-1121. (doi:10.1016/j.theriogenology.2005.07.016)

Mansouri-Attia N, Sandra O, Aubert J, Degrelle S, Everts RE, GiraudDelville C, Heyman Y, Galio L, Hue I, Yang X et al. 2009 Endometrium as an early sensor of in vitro embryo manipulation technologies. PNAS 106 5687-5692. (doi:10.1073/pnas.0812722106)

Mata-Greenwood E, Liao WX, Zheng J \& Chen DB 2008 Differential activation of multiple signalling pathways dictates eNOS upregulation by FGF2 but not VEGF in placental artery endothelial cells. Placenta 29 708-717. (doi:10.1016/j.placenta.2008.05.005)

Mayhew TM, Ohadike C, Baher PN, Crocker IP, Mitchell C \& Ong SS 2003 Stereological investigation of placental morphology in pregnancies complicated by pre-eclampsia with and without intrauterine growth restriction. Placenta 24 219-226. (doi:10.1053/plac.2002.0900)

Mayhew TM, Charnock-Jones DS \& Kaufmann P 2004a Aspects of human fetoplacental vasculogenesis and angiogenesis. III. Changes in complicated pregnancies. Placenta 25 127-139. (doi:10.1016/j.placenta. 2003.10.010)

Mayhew TM, Wijesekara J, Baker PN \& Ong SS 2004b Short communication: Morphometric evidence that villous development and fetoplacental angiogenesis are compromised by intrauterine growth restriction but not by pre-eclampsia. Placenta 25 829-833. (doi:10.1016/j.placenta.2004.04.011)

Meegdes HL, Ingenhoes MR, Peeters LL \& Exalto N 1988 Early pregnancy wastage: relationship between chorionic vascularization and embryonic development. Fertility and Sterility 49 216-220.

Miglino MA, Pereira FT, Visintin JA, Garcia JM, Meirelles FV, Rumpf R, Ambrosio CE, Papa PC, Santos TC, Carvalho AF et al. 2007 Placentation in cloned cattle: structure and microvascular architecture. Theriogenology $\mathbf{6 8}$ 604-617. (doi:10.1016/j.theriogenology.2007.04.060)

Miles JR, Farin CE, Rodriguez KF, Alexander JE \& Farin PW 2004 Angiogenesis and morphometry of bovine placentas in late gestation from embryos produced in vivo or in vitro. Biology of Reproduction $\mathbf{7 1}$ 1919-1926. (doi:10.1095/biolreprod.104.031427)

Miles JR, Farin CE, Rodriguez KF, Alexander JE \& Farin PW 2005 Effects of embryo culture on angiogenesis and morphometry of bovine placentas during early gestation. Biology of Reproduction 73 663-671. (doi:10. 1095/biolreprod.105.040808) 
Nathanielsz PW 2006 Animal models that elucidate basic principles of the developmental origins of adult diseases. ILAR Journal/ National Research Council, Institute of Laboratory Animal Resources 47 73-82. (doi:10.1093/ilar.47.1.73)

Neufeld G, Kessler O \& Herzog Y 2002 The interaction of neuropilin-1 and neuropilin-2 with tyrosine-kinase receptors for VEGF. Advances in Experimental Medicine and Biology 515 81-90.

Ostrup E, Hyttel P \& Ostrup O 2011 Embryo-maternal communication: signalling before and during placentation in cattle and pig. Reproduction, Fertility, and Development 23 964-975. (doi:10.1071/RD11140)

Palmieri C, Loi P, Reynolds LP, Ptak G \& Della Salda L 2007 Placental abnormalities in ovine somatic cell clones at term: a light and electron microscopic investigation. Placenta 28 577-584. (doi:10.1016/j.placenta.2006.08.003)

Palmieri C, Loi P, Ptak G \& Della Salda L 2008 Review paper: A review of the pathology of abnormal placentae of somatic cell nuclear transfer clone pregnancies in cattle, sheep, and mice. Veterinary Pathology $\mathbf{4 5}$ 865-880. (doi:10.1354/vp.45-6-865)

Patan S 2000 Vasculogenesis and angiogenesis as mechanisms of vascular network formation, growth and remodeling. Journal of Neuro-Oncology 50 1-15. (doi:10.1023/A:1006493130855)

Patel J, Landers K, Mortimer RH \& Richard K 2010 Regulation of hypoxia inducible factors (HIF) in hypoxia and normoxia during placental development. Placenta 31 951-957. (doi:10.1016/j.placenta.2010.08.008)

Pringle KG, Kind KL, Sferruzzi-Perri AN, Thompson JG \& Roberts CT 2010 Beyond oxygen: complex regulation and activity of hypoxia inducible factors in pregnancy. Human Reproduction Update $\mathbf{1 6}$ 415-431. (doi:10.1093/humupd/dmp046)

Ptak GE, D'Agostino A, Toschi P, Fidanza A, Zacchini F, Czernik M, Monaco F \& Loi P 2013 Post-implantation mortality of in vitro produced embryos is associated with DNA methyltransferase 1 dysfunction in sheep placenta. Human Reproduction 28 298-305. (doi:10.1093/humrep/des397)

Purcell TL, Given R, Chwalisz K \& Garfield RE 1999 Nitric oxide synthase distribution during implantation in the mouse. Molecular Human Reproduction 5 467-475. (doi:10.1093/molehr/5.5.467)

Rajakumar A, Jeyabalan A, Markovic N, Ness R, Gilmour C \& Conrad KP 2007 Placental HIF-1 $\alpha$, HIF-2 $\alpha$, membrane and soluble VEGF receptor-1 proteins are not increased in normotensive pregnancies complicated by late-onset intrauterine growth restriction. American Journal of Physiology. Regulatory, Integrative and Comparative Physiology 293 766-774. (doi:10.1152/ajpregu.00097.2007)

Redmer DA, Wallace JM \& Reynolds LP 2004 Effect of nutrient intake during pregnancy on fetal and placental growth and vascular development. Domestic Animal Endocrinology 27 199-217. (doi:10.1016/j.domaniend.2004.06.006)

Redmer DA, Aitken RP, Milne JS, Reynolds LP \& Wallace JM 2005 Influence of maternal nutrition on messenger RNA expression of placental angiogenic factors and their receptors at mid-gestation in adolescent sheep. Biology of Reproduction 72 1004-1009. (doi:10.1095/biolreprod.104.037234)

Redmer DA, Luther J, Milne J, Aitken R, Johnson M, Borowicz P, Borowicz M, Reynolds LP \& Wallace J 2009 Fetoplacental growth and vascular development in overnourished adolescent sheep at day 50,90 and 130 of gestation. Reproduction 137 749-757. (doi:10.1530/REP-08-0516)

Regnault TR, Orbus RJ, de Vrijer B, Davidsen ML, Galan HL, Wilkening RB \& Anthony RV 2002 Placental expression of VEGF, PIGF and their receptors in a model of placental insufficiency-intrauterine growth restriction (PI-IUGR). Placenta 23 132-144. (doi:10.1053/plac.2001.0757)

Rennie MY, Detmar J, Whiteley KJ, Yang J, Jurisicova A, Adamson SL \& Sled JG 2011 Vessel tortuosity and reduced vascularization in the fetoplacental arterial tree after maternal exposure to polycyclic aromatic hydrocarbons. American Journal of Physiology. Heart and Circulatory Physiology 300 675-684. (doi:10.1152/ajpheart.00510.2010)

Reynolds LP 1986 Utero-ovarian interactions during early pregnancy: role of conceptus induced vasodilation. Journal of Animal Science 62 47-61.

Reynolds LP \& Caton JS 2012 Role of the pre- and post-natal environment in developmental programming of health and productivity. Molecular and Cellular Endocrinology 354 54-59. (doi:10.1016/j.mce.2011.11.013)

Reynolds LP \& Redmer DA 1992 Growth and microvascular development of the uterus during early pregnancy in ewes. Biology of Reproduction 47 698-708. (doi:10.1095/biolreprod47.5.698)
Reynolds LP \& Redmer DA 1995 Utero-placental vascular development and placental function. Journal of Animal Science 73 1839-1851.

Reynolds LP \& Redmer DA 2001 Angiogenesis in the placenta. Biology of Reproduction 64 1033-1040. (doi:10.1095/biolreprod64.4.1033)

Reynolds LP, Borowicz PP, Vonnahme KA, Johnson ML, Grazul-Bilska AT, Wallace JM, Caton JS \& Redmer DA 2005 Animal models of placental angiogenesis. Placenta 26 689-708. (doi:10.1016/j.placenta.2004.11.010)

Reynolds LP, Caton JS, Redmer DA, Grazul-Bilska AT, Vonnahme KA, Borowicz PP, Luther JS, Wallace JM, Wu G \& Spencer TE 2006 Evidence for altered placental blood flow and vascularity in compromised pregnancies. Journal of Physiology 572 51-58.

Reynolds LP, Borowicz PP, Caton JS, Vonnahme KA, Luther JS, Buchanan DS, Hafez SA, Grazul-Bilska AT \& Redmer DA 2010 Utero-placental vascular development and placental function: an update. International Journal of Developmental Biology 54 355-366. (doi:10.1387/ijdb.082799lr)

Reynolds LP, Vonnahme KA, Lemley CO, Redmer DA, Grazul-Bilska AT, Borowicz PP \& Caton JS 2013 Maternal stress and placental vascular function and remodeling. Current Vascular Pharmacology 11 564-593. (doi:10.2174/1570161111311050003)

Ruiz-Gonzalez I, Sanchez MA, Garcia-Fernandez RA, Garcia-Palnecia P, Sanchez B, Gonzalez-Bulnes A \& Flores JM 2013 Different influence of ovine estrus synchronization treatments on caruncular early angiogenesis. Histology and Histopathology 28 373-383.

SAS Institute 2010 SAS User's Guide, Statistics, 5th edn. Cary, NC: Statistical Analysis System Institute.

Sellers López F, Orozco-Beltran D, Gil-Guillen V, Lozano JM, Palacios A \& Bernabeu R 2010 Analysis of placental vascularization by means of 3D Power Doppler in women pregnant following oocyte donation. Reproductive Sciences 17 754-759. (doi:10.1177/1933719110371013)

Shimizu T, Hoshino Y, Miyazaki H \& Sato E 2012 Angiogenesis and microvasculature in the female reproductive organs: physiological and pathological implications. Current Pharmaceutical Design 18 303-309. (doi:10.2174/138161212799040367)

Sinclair KD 2008 Assisted reproductive technologies and pregnancy outcomes: mechanistic insights from animal studies. Seminars in Reproductive Medicine 26 153-161. (doi:10.1055/s-2008-1042954)

Spencer TE, Sandra O \& Wolf E 2008 Genes involved in conceptusendometrial interactions in ruminants: insights from reductionism and thoughts on holistic approaches. Reproduction 135 165-179. (doi:10.1530/REP-07-0327)

Stenbak TK, Redmer DA, Berginski HR, Erickson AS, Navanukraw C, Toutges MJ, Bilski JJ, Kirsch JD, Kraft KC, Reynolds LP et al. 2001 Effects of follicle stimulating hormone (FSH) on follicular development, oocyte retrieval, and in vitro fertilization (IVF) in ewes during the breeding season and seasonal anestrus. Theriogenology 56 51-64. (doi:10.1016/ S0093-691X(01)00542-8)

Tomic V \& Tomic J 2011 Neonatal outcome of IVF singletons versus naturally conceived in women aged 35 years and over. Archives of Gynecology and Obstetrics 284 1411-1416. (doi:10.1007/s00404-011-1873-2)

Vonnahme KA \& Lemley CO 2011 Programming the offspring through altered uteroplacental hemodynamics: how maternal environment impacts uterine and umbilical blood flow in cattle, sheep and pigs. Reproduction, Fertility, and Development 24 97-104. (doi:10.1071/RD11910)

Wulff C, Weigand M, Kreienberg R \& Fraser HM 2003 Angiogenesis during primate placentation in health and disease. Reproduction 126 569-577. (doi:10.1530/rep.0.1260569)

Ziebell BT, Galan HL, Anthony RV, Regnault TR, Parker TA \& Arroyo JA 2007 Ontogeny of endothelial nitric oxide synthase mRNA in an ovine model of fetal and placental growth restriction. American Journal of Obstetrics and Gynecology 197 420e1-420e5. (doi:10.1016/j.ajog.2007.07.016)

Zygmunt M, Herr F, Münstedt K, Lang U \& Liang OD 2003 Angiogenesis and vasculogenesis in pregnancy. European Journal of Obstetrics, Gynecology, and Reproductive Biology 110 S10-S18. (doi:10.1016/ S0301-2115(03)00168-4)

Received 20 December 2013

First decision 23 January 2014

Revised manuscript received 23 January 2014

Accepted 28 January 2014 